\title{
INTERthesis
}

\section{AMÉLIA BEVILÁQUA QUE ERA MULHER DE VERDADE: A MEMÓRIA CONSTRUÍDA DA ESPOSA DE CLÓVIS BEVILÁQUA. ${ }^{1}$}

Wilton Carlos Lima da Silva²

\section{Resumo:}

A partir de quatro biografias sobre o jurista Clóvis Beviláqua, que apresentam três estigmas do personagem - ser filho de padre, se envolver em uma grande polêmica jurídico gramatical com Rui Barbosa na confecção do Código Civil de 1917 e ter uma esposa de modos exóticos - busca-se discutir a memória construída de Amélia Carolina de Freitas Beviláqua, que fica marcada como pioneira do movimento feminista no Brasil e também como escritora arrivista que ambicionou entrar para a Academia Brasileira de Letras; dona de casa relapsa; mulher pouco vaidosa e desalinhada no vestir; esposa leviana ou adúltera, entre outras adjetivações negativas.

Palavras-chaves: Clóvis Beviláqua. Amélia Carolina de Freitas Beviláqua. Biografia. Memória.

\section{INTRODUÇÃO}

"Biografia das mulheres: até os trinta anos, cronologia; depois, mitologia." (Hippolyte Jean Giraudoux O jurista Clóvis Beviláqua (1859-1944) ocupou posição privilegiada entre os "brasileiros notáveis" do contexto de transição do século XIX para as primeiras décadas do século $X X$ no Brasil, como membro destacado de uma elite política e intelectual, tendo sido professor na Faculdade de Direito de Recife, autor do Código Civil de 1917, consultor do Ministério das Relações Exteriores e jurista de prestígio internacional, além de crítico literário e autor de livros de direito, filosofia e história.

Suas biografias enfatizam a amplitude de seus conhecimentos jurídicos, os méritos da codificação civil da qual foi autor e o modo de vida humilde e generoso que the valeu a alcunha de "santo laico".

\footnotetext{
${ }_{1}$ O presente trabalho faz parte de pesquisa que contou com apoio financeiro do Conselho Nacional de Desenvolvimento Científico e Tecnológico (CNPq).

${ }^{2}$ Doutor em História pela Universidade Estadual Paulista Júlio de Mesquita Filho, UNESP, Campus de Assis. Professor Livre Docente do Departamento de História na UNESP, Campus de Assis. Assis, SP, Brasil. E-mail: wilton@assis.unesp.br
}

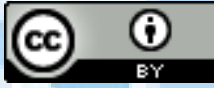
Esta obra foi licenciada com uma Licença Creative Commons - Atribuição 3.0 Não Adaptada. 
Por outro lado, três estigmas surgem nessas mesmas biografias: o fato de ser filho de padre, a polêmica jurídico-gramatical com Rui Barbosa durante a confecção do Código Civil de 1917 e a sua relação com a esposa, Amélia de Freitas Beviláqua.

A condição de filho de um padre, portanto concebido fora da instituição do matrimônio, que não era rara no Brasil do século XIX, o coloca na mesma situação de outros ilustres: José de Alencar (cujo pai - o senador José Martiniano de Alencar - viveu maritalmente com uma prima, Ana Josefina, com quem teve oito filhos), José do Patrocínio (filho de uma jovem quitandeira chamada Justina e do pároco da capela imperial, João Carlos Monteiro - que não Ihe reconheceu a paternidade, mas encaminhou-o), Diogo Antônio Feijó (batizado como "filho de pais incógnitos", mas que, segundo alguns pesquisadores, seria filho do vigário Manuel da Cruz Lima), Teodoro Fernandes Sampaio (filho de uma escrava com o sacerdote Manuel Fernandes Sampaio, que the comprou a alforria e cuidou para que o menino tivesse uma boa educação), entre outros. ${ }^{3}$

Sobre a polêmica no processo de codificação civil, quando Rui Barbosa, como paladino do purismo gramatical e do resguardo da linguagem jurídica na redação da obra, despejou pesadas críticas ao projeto de Clóvis Beviláqua, deu início a uma enorme celeuma. Juristas, intelectuais, políticos e instituições (o Supremo Tribunal Federal, as diversas faculdades de Direito e o Instituto da Ordem dos Advogados, entre outras) se manifestaram sobre a correta linguagem para a redação da codificação, mas esta é avaliada atualmente apenas como resultado de uma disputa política entre grupos da república oligárquica e fruto da tensão entre concepções distintas de codificação jurídica e estilo retórico-literário no interior do discurso jurídico, que não diminui nem os resultados da obra nem os envolvidos.

Finalmente, a relação do jurista com sua esposa, Amélia Carolina de Freitas Beviláqua, que adotava modos excêntricos frente à sociedade da época, rendeu à mulher uma memória construída a partir de diferentes imagens: escritora arrivista que ambicionou entrar para a Academia Brasileira de Letras; dona de casa relapsa, que permitia que animais domésticos habitassem no interior da residência; mulher

\footnotetext{
${ }^{3}$ De certa forma, a trajetória de Clóvis Beviláqua parece refletir algumas das tensões desse contexto pessoal, pois criado em uma situação de relativa tolerância e usufruindo das vantagens dessa situação torna-se republicano e positivista refratário à Igreja enquanto instituição, como pai foi levado pelos preconceitos de sua época a assumir como suas as filhas de sua filha, e enquanto pensador e jurista se mostrou sensível às questões sociais (entre as quais a questão dos filhos ilegítimos).
}

R. Inter. Interdisc. INTERthesis, Florianópolis, v.11, n.2, p.138-161, Jul-Dez. 2014
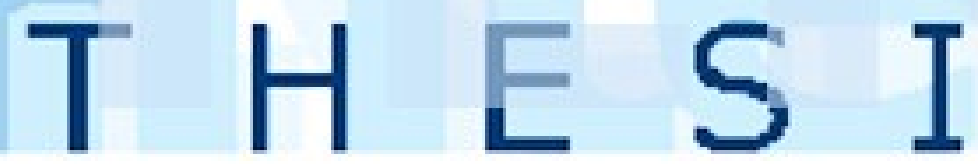
pouco vaidosa e desalinhada no vestir; esposa leviana ou adúltera, entre outras adjetivações negativas.

A partir de quatro biografias de Clóvis Beviláqua, escritas por Lauro Romero (1956), Raimundo Menezes e Ubaldino de Azevedo (1959), Noemia Paes Barreto Brandão (1989) e Silvio Meira (1990), pretendemos contextualizar como essas imagens de Amélia Beviláqua foram construídas e explicitadas. ${ }^{4}$

\section{QUATRO BIOGRAFIAS}

As biografias escolhidas oferecem diferentes perspectivas sobre o jurista e sua memória, a partir dos pertencimentos de seus autores assim como das condições nas quais foram geradas: Lauro Romero, filho de Silvio Romero, faz um tributo ao homem bom e justo que foi amigo de seu pai; Raimundo Menezes e Ubaldino de Azevedo (1959), ambos advogados, produzem uma monografia para um concurso cívico que comemora o centenário do jurista, caracterizando seu texto como uma memória entre pares; Noemia Paes Barreto Brandão (1989), que foi amiga de infância das filhas do personagem oferece uma abordagem na qual a monumentalidade é acompanhada pela intimidade; e, finalmente, Silvio Meira (1990), civilista de renome, se propõe a abordar a trajetória profissional e intelectual do autor do Código Civil, mas todas abordam os três estigmas e, em particular, a figura da esposa. ${ }^{5}$

Amélia Carolina de Freitas Beviláqua (1860-1946), filha de tradicional família piauiense, casou-se com o jovem e humilde advogado Clóvis Beviláqua em 1883, sendo filha de desembargador, diferente da maioria das mulheres de sua geração, tivera professor particular para ensinar-lhe a escrita e a matemática, assim como para desenvolver-Ihe o hábito da leitura.

\footnotetext{
${ }^{4}$ Não se colocam dentro dos limites deste texto as discussões sobre as particularidades da escrita biográfica e sua historicidade, mas ao leitor interessado sugerimos os trabalhos de Arfuch (2010), Brackschreider (2001), Dosse (2007) e Loriga (2011) como leituras fundamentais.

${ }^{5}$ As quatro biografias adotam uma clara perspectiva hagiográfica em relação ao jurista, reafirmando dimensões consagradas de sua memória, sendo que, em geral, as fontes utilizadas são de conhecimento público e expressam dimensões profissionais e intelectuais. Os destaques possíveis são a presença no trabalho de Brandão (1989) do uso de alguns documentos pessoais e familiares que ainda não haviam sido pesquisados, além da memória pessoal da biógrafa, e no caso de Meira (1990) a minúcia da pesquisa em moldes historicistas, que permite a correção de alguns pequenos erros e a expressão exata de certos dados sobre a trajetória do personagem. Logicamente, a imagem de Amélia Beviláqua é tratada de forma ligeira e panorâmica em todas as quatro, dimensionada somente enquanto esposa do advogado.
}

R. Inter. Interdisc. INTERthesis, Florianópolis, v.11, n.2, p.138-161, Jul-Dez. 2014
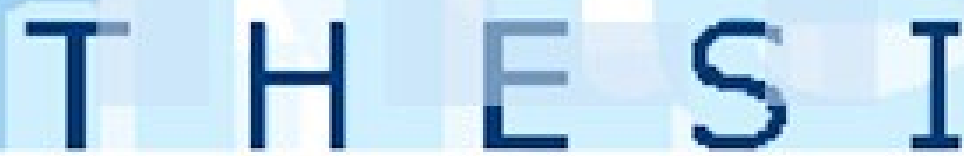
Após o casamento, entre idas e vindas o casal se transferiu para o Rio de Janeiro e ela, com o marido e as filhas, moraram durante décadas em casa modesta e alugada na Rua Barão de Mesquita, número 272, no bairro pobre do Andaraí somente adquirida pela família após a sua morte com a ajuda da Caixa Econômica rodeada por um jardim mal cuidado, cercada por diversos animais domésticos e aonde os moradores ao mesmo tempo em que demonstravam certo desapego aos bens materiais conviviam com constantes dificuldades econômicas.

Segundo Meira (1990, p. 81-83) o relacionamento de Clóvis Beviláqua e Amélia de Freitas Beviláqua foi terreno fértil para "várias histórias fantasiosas", com inúmeros episódios formando um "repertório quase folclórico" com narrativas "que já se tornaram legendárias, algumas de caráter anedótico, outras pitorescas", e vaticina:

Tudo isso, no entanto, em vez de macular a veneranda figura ou alterar-lhe a imagem, pelo contrário, constitui a moldura em que se encaixa a sua personalidade. Felizes os homens que conseguem, durante a vida, criar em torno de si uma aura de admiração a ponto de despertar, em mentes imaginosas, invenções quase fantásticas. Algumas devem ser verdadeiras, mas aumentadas, coloridas pela tradição oral, com os exageros naturais de quem passa um conto e lhe aumenta um ponto. (p. 81)

Segundo Falci (s.d., p. 3) a memória da esposa do jurista foi mantida da seguinte forma:

\begin{abstract}
Amélia de Freitas Beviláqua é lembrada, ainda hoje, por pessoas já de certa idade que, com ela conviveram no Rio de Janeiro nas décadas de trinta e quarenta do século XX por apresentar atitudes 'modernistas' de vanguarda, consideradas até um tanto ou quanto amalucadas. Lembrada como dona de casa excêntrica, onde os animais domésticos disputavam espaços nos sofás e poltronas, onde a banheira servia como ninho para galinhas em choco e onde os pombos e galos voavam por sobre as cabeças dos visitantes; ou como desalinhada e de mau aspecto sob o ponto de vista físico; lembrada ainda como de comportamento avançado sob o ponto de vista moral; muitos esquecem o valor literário que Amélia possuiu.
\end{abstract}

A adjetivação sobre Amélia pode ter diversas origens que nascem da misoginia ou do conservadorismo do período: sua autonomia como mulher, sua qualidade como literata, o tipo de obra que construiu, sua audácia em se candidatar à Academia Brasileira de Letras, seu modo de vida, entre outros aspectos.

A construção da memória da escritora e feminista se torna limitada a redução de sua identidade enquanto esposa de um notável e às avaliações sobre a forma como cumpriu tal papel social, de modo que as dimensões estética e intelectual de

R. Inter. Interdisc. INTERthesis, Florianópolis, v.11, n.2, p.138-161, Jul-Dez. 2014
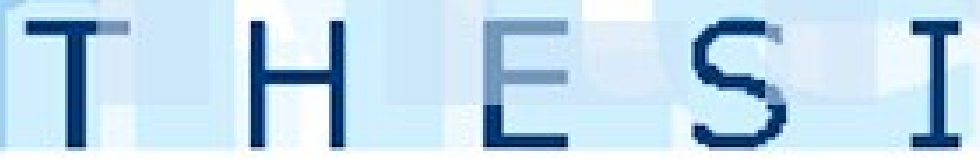
seu trabalho, modernizadora e contestadora de suas ideias, e corajosa e visionária de seus atos se tornam parte de desmemorias do período.

Sem dúvida, a trajetória da personagem e a memória dela construída refletem as tensões que envolveram a condição feminina nas primeiras décadas do século $\mathrm{XX}$, marcada por transformações do comportamento feminino, em sintonia com os processos de urbanização, nos quais as mulheres buscam se libertar dos espartilhos, assumir comportamentos mundanos ligados a uma sociabilidade moderna em contraste com a resistência no ambiente familiar e doméstico no qual o padrão de comportamento hegemônico burguês estabelece rigidamente os papéis sociais definidos para o homem e para a mulher, respectivamente, de provedor e de mantenedora da ordem doméstica. (MALUF; MOTT, 1998)

Maluf e Mott (1998, p.370 e 371) a partir de artigos publicados na Revista Feminina ${ }^{6}$ mostram o desejo das mulheres da época em buscar a sua liberdade e igualdade, ao mesmo tempo em que identificam-se como "vitimas do preconceito", que viviam fechadas no lar, arrastando "uma existência monótona, insípida, despida de ideais" e monetariamente algemadas aos maridos.

A condição feminina é cuidadosamente delimitada por esforços de conservadorismo nos quais

A imagem de mãe-esposa e dona de casa como a principal e mais importante função da mulher correspondia aquilo que era pregado pela Igreja, ensinado por médicos e juristas, legitimado pelo Estado e divulgado pela imprensa. (Maluf e Mott, 1998, p.374)

Desse modo, essas representações, de mãe e esposa, acabam por encobrir o "ser mulher", de modo que a relação com suas "obrigações" passam a delimitar o gradiente do dever ser e das prescrições que daí decorrem e que são reafirmadas por conservadores e reformistas de diferentes matizes. (MALUF; MOTT, 1998, p. 373-374)

\footnotetext{
${ }^{6}$ A Revista Feminina era "uma importante publicação com sede em São Paulo e com uma excelente distribuição. Circulou entre 1914 e 1936, contava com a colaboração de jornalistas e escritores de renome de todo o Brasil, com também de leitoras e leitores, e publicava matérias traduzidas da imprensa estrangeira. (...) Destinava-se sobretudo ao público feminino, com seções sobre comportamento feminino, relacionamento conjugal, etiqueta, culinária, moda, trabalhos manuais. Publicava contos, charges, ar tigos de assuntos gerais e muita publicidade. Os números da revista podiam ser comprados avulsamente ou por assinaturas. Vendida em todo o Brasil, alcançou uma tiragem de ate 25 mil exemplares por mês, o que a coloca entre as revistas de maior circulação no período." (Maluf e Mott, 1998, p. 639-640)
}

R. Inter. Interdisc. INTERthesis, Florianópolis, v.11, n.2, p.138-161, Jul-Dez. 2014
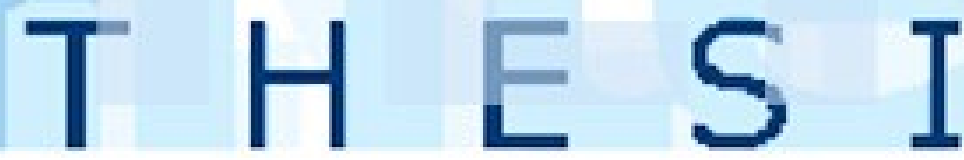
Besse (1999), estudando a construção de um novo sistema de gênero no período entre 1914 e 1940, identifica mudanças nas relações de trabalho, na educação e na própria família a partir de um desgaste na base material do poder patriarcal, através do qual a família extensa é substituída pela família nuclear burguesa urbana.

São indicadores dessas mudanças no período a forma como a imprensa aborda a questão feminina, identificando as mulheres enquanto sujeito e objeto de notícia, a literatura passa a discutir novos papéis da mulher moderna, os sindicatos lutam pelas especificidades das trabalhadoras, as feministas pressionam pelo direito de voto, e a Igreja, intelectuais e políticos passam a expressar distintas ideias sobre os papéis de gênero e a crise da família.

Por sua vez, a Era Vargas (1930-1945) afirma uma modernização que, embora estabeleça o voto feminino, ainda tem a família como base da sociedade e da organização política, produzindo uma renovação do casamento e atualização da educação dos filhos, ao mesmo tempo em que o feminismo questiona os padrões de domínio masculino sobre as mulheres.

Ações de distintos agentes buscam manter o sistema de gênero baseado em um modelo determinista e hierárquico, sendo que ao mesmo tempo em que o Estado controla o emprego feminino e adota sanções penais para o divórcio, o adultério e o abandono do lar, a igreja cria programas assistenciais para ocupar mulheres de classe média e alta na caridade como um ofício.

Por outro lado, diferentes vozes entoaram brados femininos de inconformismo e questionando a representação social que Ihes restringia as atividades econômicas e políticas, assim como a reduziam a sujeito dependente e subordinada legalmente ao homem.

É nesse contexto de disputas e mudanças que devem ser entendidas as lutas de pioneiras feministas como Bertha Lutz, Patrícia Galvão (Pagu), Maria Lacerda de Moura, e de Amélia Beviláqua, entre outras mulheres do período, enquanto esforços que foram capazes de dar visibilidade à luta das mulheres e organizar associações femininas. ${ }^{7}$

\footnotetext{
${ }^{7}$ Entre outras conquistas do movimento feminista nas primeiras décadas do século XX destacam-se a criação da Federação Brasileira pelo Progresso Feminino (1922) que se propunha a promover a educação das mulheres, conquistar direitos civis e políticos para o grupo e obter garantias legais para o trabalho feminino, a conquista do direito de voto (já no Código Eleitoral de 1932 e que foi
}

R. Inter. Interdisc. INTERthesis, Florianópolis, v.11, n.2, p.138-161, Jul-Dez. 2014
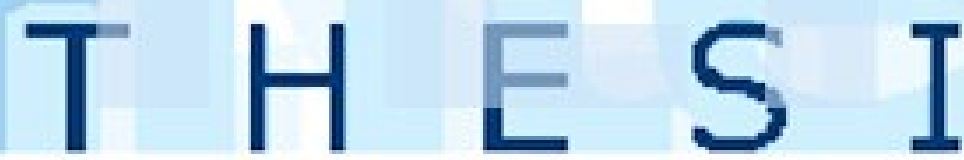


\title{
3 AMÉLIA COMO LITERATA
}

Como literata Amélia se propôs a criar uma obra que não fizesse as tradicionais concessões de uma típica literatura da época, escrita pelas mulheres e dedicadas às mulheres, não reduzindo seus textos à folhetins romanescos afrancesados, com mulheres submissas e limitadas ao papel de mães e esposas, sendo, ao contrário, recorrente os temas da paixão, da angústia e da insatisfação com a realidade.

Como autora de romances, novelas, contos e artigos, e colaboradora na fundação e edição de revistas literárias e de livros, Amélia Beviláqua se mostrou senhora de um pensamento crítico sobre as questões de estética e de gênero. ${ }^{8}$

A autora com certeza era uma mulher inteligente que se permitia ser "coquette", quando usava de humor, elegância e provocação, como em abertura de conferência no Terceiro Congresso Scientífico Latino-Americano, realizado no Rio de Janeiro, em agosto de 1905, quando ela tinha 44 anos, afirma que falará para não parecer preguiçosa, ou ainda em palestra de 1931, com 70 anos, no início do governo Vargas, afirma: "Estão em discussão o voto feminino, os direitos civis e políticos, a quebra do padrão da moeda na Inglaterra, as decadências financeiras no Brasil. Tudo isto já está enfadonho." (NEDER, 2002, p. 11e 14)

Ou quando entrevistada pelo o jornal A Noite, sobre se a mulher poderia participar em um júri forense, ela respondeu:

\begin{abstract}
Stuart Mill, Bridel e muitos estrangeiros foram sempre partidários da elevação da mulher, alguns foram mesmo fanáticos... Ao menos, isso vinga e suavisa as impertinências de Schopenhauer e de Lombroso, que duvidava tanto do sexo delicado, e não o julgava absolutamente capaz de imaginação criadora e produções originais. (...) Apesar de tantas oposições as coisas tomaram os caminhos da justiça e da razão. As mulheres que agora são simplesmente eleitoras em breves dias subirão talvez à Câmara, ao Senado, aos ministérios e quem sabe? Às interventorias. Se elas podem galgar todos esses postos e já estão designadas, segundo me informaram, para a elaboração da futura carta constitucional, por que, pergunto eu, não
\end{abstract}

incorporado a Constituição de 1934), assim como a eleição de uma deputada feminista (Bertha Lutz, 1936).

8 São obras de Amélia Beviláqua: "Alcyone - Bahia, 1902; Aspectos - Recife, 1906; Instrução e Educação da Infância - Recife, 1906; Através da Vida - Rio 1906; Silhouettes - Rio 1906; Literatura e Direito (em colaboração com Clóvis) - Bahia, 1907; Vesta - Rio, 1908; Angústia -Rio, 1913; Açucena Rio, 1921; Jeannette - Rio, 1923; Milagre do Natal - Rio, 1928; Impressões - Rio, 1929; A Academia Brasileira de Letras e Amélia de Freitas Beviláqua - Rio, 1930; Flor do Orfanato - Rio, 1931; Divagações, (Rio,) 1931; Recordação do dia 7 de agosto de 1933 - Rio, 1933; Alma Universal - Rio, 1935". (FALCl, s.d., p. 3)

R. Inter. Interdisc. INTERthesis, Florianópolis, v.11, n.2, p.138-161, Jul-Dez. 2014
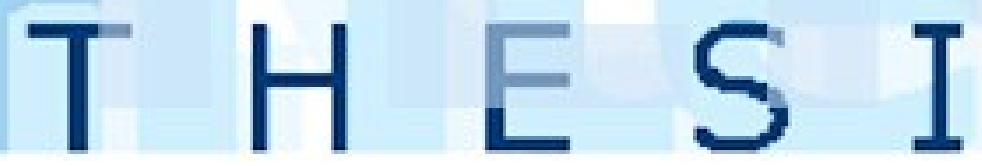
entrarão elas também no júri em que se apura e depura a reação da sociedade contra o crime? (A NOITE, 29/09/1932, apud FALCl, s.d., p. 5)

Menezes e Azevedo (1959, p. 310) afirmam que em relação ao valor literário da produção de Amélia Beviláqua entre a crítica literária "há os que a louvavam, exageradamente, e os que opõem restrições aos temas, inexpressivos ou por vezes ingênuos", embora a reconheçam como uma das pioneiras de literatura feminina no país (juntamente com Úrsula Garcia, Júlia Lopes de Almeida, Alba Valdez, Gilka Machado, Rosália Sandoval, Maria Clara da Cunha Freire, e outras). ${ }^{9}$

Os elogios e as ressalvas não permitem uma avaliação dos reais méritos da obra, que mesmo incensada por Silvio Romero, Araripe Júnior ou Rocha Pombo, entre outros, foi criticada por Humberto de Campos e Agripino Grieco, entre outros, como manifestação de duas dimensões importantes: a questão de gênero na qual a literatura feminina é vista como algo menor, e as formas de sociabilidade do mundo literário da Belle Époque no país quando a avaliação subjetiva da apreciação ou depreciação se ligava tanto aos vínculos de afeto ou desafeto quanto à aproximações institucionais ou disputas políticas e estéticas.

\section{A CANDIDATURA PARA A ACADEMIA BRASILEIRA DE LETRAS.}

A Academia Brasileira de Letras foi fundada no Rio de Janeiro em 20 de julho de 1897, por um grupo de escritores e intelectuais que desejavam criar uma academia nacional nos moldes da Academia Francesa. Composta por quarenta membros efetivos e perpétuos e por vinte sócios estrangeiros, a instituição deveria ser apolítica e voltada ao culto da grande arte, particularmente a literária, e a preservação da língua portuguesa.

Nascida no início do período republicano a instituição buscou ao mesmo tempo o reconhecimento e apoio financeiro do Estado e a institucionalização do campo literário no país, e se a dimensão política era negada por seus membros e estatutos, a realidade de um novo regime dividia os primeiros imortais em dois grupos, de monarquistas e de republicanos, embora todos estivessem unidos pelas

\footnotetext{
9 Falci (2001) afirma que "(A obra de Amélia) É uma produção ficional (sic), tida como feminista, de carácter bem independente que nada se assemelha a que está sendo produzida pelas mulheres na época. (...) Fosse influenciada ou não por Clóvis o certo é que a produção de Amélia era nitidamente superior às que estavam em moda e escrita pelas mulheres e dedicadas às mulheres." (p. 2-3)
}

R. Inter. Interdisc. INTERthesis, Florianópolis, v.11, n.2, p.138-161, Jul-Dez. 2014
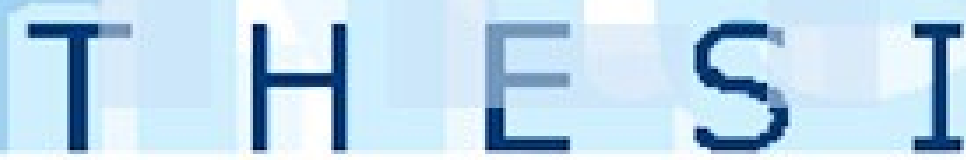
condições adversas de seus trabalhos enquanto literatos e pelo desejo de notoriedade.

Al Far (2000) e Rodrigues (2001) demonstram como a instituição não obteve sucesso, ao longo de sua existência, na tarefa de ser uma "torre de marfim", distante das pequenas questões políticas da sociedade, como definiu seu fundador Machado de Assis no discurso inaugural.

É inegável que a Academia, para além de qualquer abordagem laudatória ou invectiva, refletiu grandes disputas políticas tanto nos seus rituais internos, quanto em seus objetivos maiores expressos nos estatutos, resultando em tensões decorrentes de disputas políticas e estéticas que produziram "insuperáveis discordâncias e ácidas recriminações".

Entre diversas situações que demonstravam a dificuldade da instituição em isolar-se frente às tensões políticas externas podemos destacar a polêmica despertada a partir da apresentação de uma carta, redigida em 29 de maio de 1930, por Amélia de Freitas Beviláqua, com solicitação do aceite de sua candidatura para concorrer a uma vaga na instituição.

Embora a escritora justificasse a sua pretensão de candidatar-se a partir de sua significativa produção literária e jornalística, além de ter sido fundadora de uma das primeiras revistas mensais escrita exclusivamente por mulheres e destinada à mulheres, o episódio foi tratado pelos imortais de forma superficial e misógina, caracterizando a escritora como beletrista provinciana (pertencente à Academia Piauiense de Letras) que deixou perplexa e embaraçada a Academia Brasileira de Letras com sua reivindicação. ${ }^{10}$

Os imortais, divididos entre aqueles que entendiam que de acordo com o regimento institucional somente literatos do sexo masculino deveriam ser aceitos (como na Academia Francesa, Gouncourt e Italiana) e os que defendiam a inclusão de brasileiros - homens ou mulheres - com obras de destacado valor literário, votaram e, por catorze votos a sete, negaram à Amélia Beviláqua o direito da candidatura.

10 Fanini (2009) estuda a perspectiva "androcêntrica" da relação da Academia Brasileira de Letras com as mulheres escritoras, entre 1897 e 2003, abordando desde a exclusão de Júlia Lopes de Almeida excluída do rol de agremiados por ocasião da fundação da instituição (1897), passando pela negativa à Amélia Beviláqua (1930), e chegando à alteração dos estatutos para a aceitação da presença feminina (1976) até a presença de Rachel de Queiroz, Dinah Silveira de Queiroz, Lygia Fagundes Telles, Nélida Piñon, Zélia Gattai e Ana Maria Machado (2003).

R. Inter. Interdisc. INTERthesis, Florianópolis, v.11, n.2, p.138-161, Jul-Dez. 2014
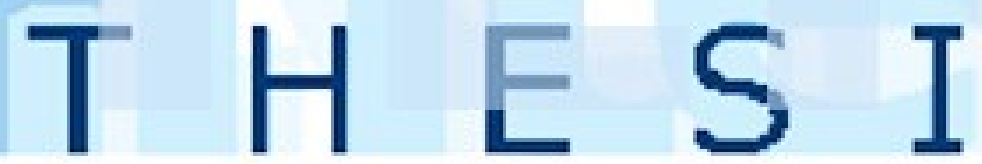
A descrição da votação feita por Humberto de Campos mostra, mesmo que de forma ligeira e distorcida, algumas das tensões e paixões presentes na discussão:

\begin{abstract}
Aberta a sessão. Aloísio de Castro, presidente, submete à apreciação dos estatutos da casa a preliminar: deve-se, ou não, diante dos estatutos, fazer a inscrição de um candidato do sexo feminino? Há opiniões, favoráveis, em virtude de compromissos tomados recentemente em entrevistas à imprensa, quando procuraram tornar-se amáveis com as mulheres. Adelmar Tavares é desse número. Luis Carlos confessa: Que hei de fazer, meu velho? Eu sou contra; mas já disse publicamente que era a favor. Agora, tenho que sustentar o que disse... Afonso Celso é favorável porque Maria Eugênia, sua filha, é candidata. Sincero, unicamente Augusto Lima, que se apega, aliás, a um argumento digno de sua mentalidade, formada em Minas em 1882: descobre ele que, gramaticalmente, quando se diz "brasileiros", significa indivíduos de ambos os sexos nascidos no Brasil. Constancio Alves lê um voto contrário, interessantíssimo e virtuoso. Dou a minha opinião: Não se trata de interpretação gramatical, mas de interpretação histórica. Urge, pois, que os fundadores da Academia, sobreviventes, informem o espírito com que foi redigido aquele artigo dos estatutos. Coelho Neto informou que, num encontro com Lúcio de Mendonça, este, referindo-se à pretensão de uma poetisa do tempo, Ihe dissera que a Academia era séria, e não admitia mulheres. Silva Ramos, na sua qualidade de membro da primeira diretoria, depõe, batendo nervosamente na mesa da sua bancada: Eu posso dizêre, e afirmáre, que, quando votamos os estatutos, e escrevemos a palavra brasileiros," nos referimos unicamente a brasileiros "macho"! Riso alegre, de todos. $\mathrm{E}$ a inscrição de $\mathrm{D}$. Amélia é recusada por quatorze votos contra sete, com grande alivio mesmo dos que votaram a favor. (MENDES, 2006, p. 175-176)
\end{abstract}

O episódio permitiu diversas manifestações de descaso, chacota e sexismo por parte dos imortais, como no diálogo narrado por Venâncio Filho (2006, p. 16) entre Roquette-Pinto e Ataulfo de Paiva no qual o primeiro se diz favorável ao ingresso de mulheres na $A B L$ desde que maiores de quarenta e cinco anos, e o segundo perguntando onde seria possível encontrar mulheres que confessassem ter mais de quarenta e cinco anos de idade?

Fanini (2009, p. 213-216) também acrescenta o diálogo entre Constâncio Alves e Silva Ramos que defenderam a fundação de instituições exclusivamente femininas (fazendo um paralelo com os conventos), o chiste de Rodrigo Octávio que definiu a situação como uma "consulta saial", e a questão de Olegário Mariano sobre qual vestimenta as mulheres usariam se fossem admitidas (colocando o hábito de freira ou o quimono japonês como opções).

Um bom exemplo sobre a vida literária e as redes de relações no período aparece na descrição feita por Adolfo Caminha sobre os rituais de apresentação do literato para seus pares:

R. Inter. Interdisc. INTERthesis, Florianópolis, v.11, n.2, p.138-161, Jul-Dez. 2014
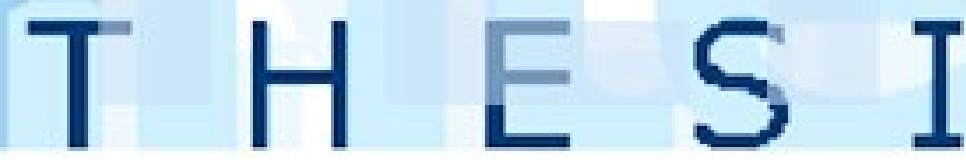
Há quase sempre, direi mesmo sempre, má vontade para os que ousam estrear na literatura sem uma carta, sem um bilhete de apresentação, uma formalidadezinha diplomática, um pedido afetuoso, alguma causa oficial e solene. O poeta deve se mostrar humilde, "bom mancebo", um pouco tímido sem parecer tolo demais, e confessar imediatamente as suas culpas, isto é, dizer-se idólatra do Sr. Silvio Romero, admirador absoluto do Sr. Valentim Magalhães, e discípulo do Sr. Luiz Delfino. Atualmente é um bom conselho dizer o que pensa em matéria de política republicana. A política já vai penetrando no domínio da literatura e das artes. (CAMINHA, 1999, p. 18-19)

Em um período no qual pouquíssimos literatos eram capazes de viver exclusivamente da produção de obras autorais, e a imensa maioria dependia de uma rede de relações capaz de oferecer uma "base de sustentação" financeira e intelectual, a carreira literária se ancorava em três sustentáculos que não se apresentavam ao alcance da maioria das mulheres: "a colaboração continuada na imprensa (jornais e revistas ilustradas), a produção de obras autorais, e a inserção no serviço público em condições de interferir o mínimo possível nas atividades propriamente intelectuais." (MICELI, 1996, p. 18).

Assim, as mulheres, em sua maioria reduzidas à condição de esposas e donas de casa, terão de se utilizar de diferentes estratégias para se moverem no interior desses limites institucionais, ao mesmo tempo em que terão suas obras avaliadas dentro de um gradiente que inclui referências de condescendência e de misoginia.

Os preconceitos de gênero que parecem ser despertados por Amélia Beviláqua também se manifestaram contra outras escritoras, se destacando por seu nível de violência os ataques contra Gilka Machado, poetisa que enveredou pela poesia erótica e despertou rancores e ressentimentos de diversos literatos da época. (GOTLIB, 1982; PAIXÃO, 1990)

Trata-se do reflexo, no campo literário, das tensões do campo social no qual uma sociedade em acentuada transformação econômica e social, pela dinâmica de urbanização e industrialização em contraste com o século XIX, busca manter a mulher na esfera privada, espaço culturalmente afirmado como "feminino", em oposição ao espaço público, domínio do "masculino", e que despertam amplas expectativas que se mostram muitas vezes contraditórias, como quando a mesma mulher deve manter uma aparência agradável perante o marido, administrar o lar, ser mãe dedicada e capaz de instruir suas crianças, e manter o recato, controlar a frequência das relações sexuais e ser submissa. (MALUF; MOTT, 1998, p. 396).

A literatura feminina, identificada como fruto da intuição, do improviso e da

R. Inter. Interdisc. INTERthesis, Florianópolis, v.11, n.2, p.138-161, Jul-Dez. 2014
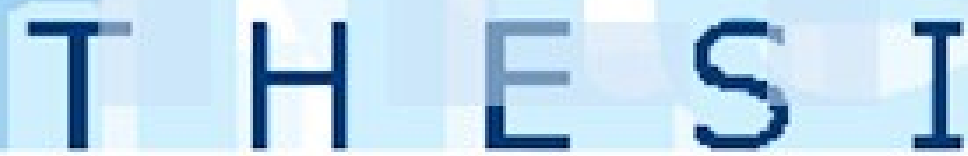
espontaneidade, em contraste com o engenho, a técnica e o talento, que seriam atributos masculinos, enfrentou "vazios institucionais" que resultaram em "esquecimentos" no quais para além das qualidades das obras reflete-se a distribuição desigual de prestígio e poder de uma sociedade "androcêntrica" e de seu cânone.

Mendes (2006, p. 168-177) fez minucioso levantamento da avaliação da obra literária de Amélia Beviláqua na história literária do país e constata que no século XIX Silvio Romero, José Veríssimo e Afrânio Peixoto não mencionam a escritora em suas obras, Araripe Júnior, João Ribeiro e Humberto de Campos tecem comentários diversos, e no século $X X$ todos os críticos consultados não citam a autora, exceto Wilson Martins que sobre o marido, Clóvis Beviláqua, aponta: “A fraqueza inocente desse homem extraordinário consistia em considerar a esposa uma escritora de talento", e sobre a mesma se refere ao episódio da candidatura à Academia Brasileira de Letras.

Trecho do Prefácio do livro Alcione, de Amélia Beviláqua, assinado por Araripe Júnior apresenta um exemplo dessa forma condescendente como a literatura feminina é tratada naquele período:

Os pequenos contos que a Exma. sra. D. Amélia Beviláqua, por excessiva delicadeza permitiu-me ler, si nenhuma preocupação literária revelam, vêm, todavia confirmar aquele juízo; a espontaneidade de seu espírito feminil, comovido diante dos fatos que penetrando a fantasia, transformam-se no relato da ficção, mostram evidentemente onde pode chegar, o seu talento, quando assíduo nesse gênero de literatura. [...] São os votos sinceros de quem subscreve estas linhas. Rio, 16 de Janeiro de 1902. T. A. Araripe Junior (MENDES, 2006, p. 169)

Ou ainda Humberto de Campos, destilando misoginia em seu Diário Secreto, avaliando a literatura feminina a partir da candidatura de Amélia Beviláqua para a Academia Brasileira de Letras:

Em verdade eu não sei de nada mais parecido com um livro de uma mulher do que outro livro de mulher. (...) (Diz ainda,) a escritora e a ficção, por maior que seja o seu talento, por mais masculino que se afigure a sua mentalidade, por menos femininos que the nasçam os pensamentos, denunciam fatalmente as inteligências menos perspicazes a sua condição (apud MENDES, 2006, p. 173-174)

Note-se que em 1929, um ano antes de se candidatar à Academia Brasileira de Letras, Amélia Beviláqua publicou um livreto intitulado Impressões, conjunto de textos nos quais a autora discorre sobre obras de João Ribeiro, Alberto de Oliveira,

R. Inter. Interdisc. INTERthesis, Florianópolis, v.11, n.2, p.138-161, Jul-Dez. 2014
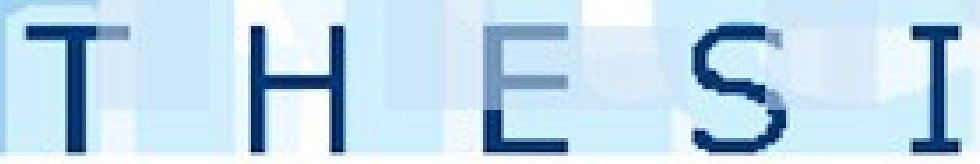
Araripe Júnior, Sílvio Romero e Rodrigo Octavio, entre outros.

Embora já na apresentação a autora identifique as obras e os autores analisados como representantes de suas últimas leituras convêm assinalar que tais escolhas contemplam um número expressivo de escritores que são membros da $A B L$ e amigos do casal Clóvis e Amélia, e que o tom elogioso do texto coloca a obra como uma ação proposital de reafirmação de vínculos afetivos e de legitimação intelectual para preparar a sua candidatura ao mesmo tempo em que busca consolidar alianças e desencorajar resistências.

Como afirma Fanini (2009, p. 202-203) as "considerações encomiásticas" de Amélia podem ser consideradas uma inegável "moeda de troca", pois a autora "no lugar de uma carta ou de um pedido, tratou logo de publicar um livro, que serviu como uma espécie de preito aos escritores consagrados", se equilibrando de forma delicada entre o público e o privado, no qual o ritual público da confissão de admiração e o exercício constrangedor da bajulação podem ser vistos como muito próximos.

No entanto, avaliando o livro Impressões, da autora, Humberto de Campos não o qualifica como "uma obra literária, mas um despretensioso manual de sentimento", sendo mais um "dos livros em prosa que aparecem frequentemente no Brasil sob a amável responsabilidade ou a encantadora irresponsabilidade, de um nome de mulher", sendo que "dez ou vinte outras senhoras escrevem, norte a sul do país, com a mesma singeleza e o mesmo vocabulário romântico, respingado, parece em Joaquim Manuel de Macedo", sendo esse superior somente porque nenhuma delas é esposa de Clóvis Beviláqua, tornando a obra um conjunto de reminiscências do casal. (MENDES, 2006, p. 173-174)

Se ambicionando se candidatar à Academia Brasileira de Letras Amélia Beviláqua organiza Impressões, após a recusa de sua candidatura pela instituição organiza um novo livro, A Academia Brasileira de Letras e Amélia de Freitas Beviláqua, tendo como subtítulo "Documentos Históricos e Literários, referentes à recusa de sua inscrição à vaga da Academia".11

\footnotetext{
11 "Aliás, a negativa da ABL foi eclipsada pela documentação produzida pelos próprios acadêmicos, já que tanto as Atas quanto os textos que compõem o acervo da agremiação não fazem menção ao interesse de Amélia Beviláqua em integrar o grupo dos imortais brasileiros, tanto que seu nome sequer chega a ser incluído na lista de candidatos à vaga por ela pleiteada. $E$ quanto a isso, não fosse a iniciativa da preterida em registrar o episódio e publicá-lo, nele enfeixando suas impressões, bem como os artigos que outros escritores produziram sobre o assunto, dele não restariam mais do
}

R. Inter. Interdisc. INTERthesis, Florianópolis, v.11, n.2, p.138-161, Jul-Dez. 2014
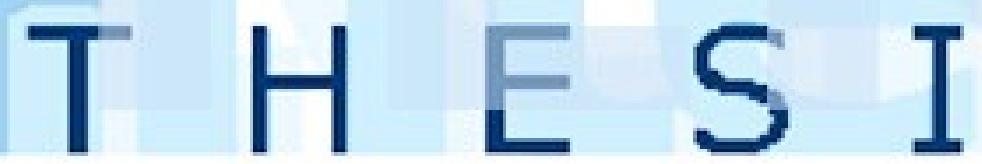
O livro surge como um desabafo pelo revés sofrido e ao mesmo tempo um enfrentamento aos "imortais misoginistas" e à "maçonaria das letras", reafirmando seu vínculo ao mundo literário através das manifestações de apoio recebidas.

O livro cumpre duas funções, ao registrar de forma clara os preconceitos dos quais a autora fora vítima, pois ao mesmo tempo em que legitima sua pretensão e dimensiona o componente misógino da Academia também estabelece um contraponto de afirmação da memória pessoal, de literata e de mulher, em contraste com o silêncio da instituição.

Clóvis Beviláqua escreve um artigo no Jornal do Comércio (de 08 de junho) intitulado "Inelegibilidade de Senhoras para a Academia Brasileira de Letras" que classificava a decisão de "absona" (dissonante), irracional, injusta e conservadora e a partir desse incidente não mais frequentou a instituição (da qual participara da fundação em 1897). ${ }^{12}$

O jurista não só protestou contra a recusa dos acadêmicos em permitir a candidatura de sua esposa, argumentando de forma incisiva - embora insuficiente para reverter a decisão - como também se desligou publicamente da instituição após o ocorrido, se recusando, inclusive a receber os jetons a que tinha direito como membro, só não se desvinculando completamente porque uma vez eleito o cargo é vitalício. ${ }^{13}$

\section{A ESPOSA E A ADÚLTERA}

Alguns autores apontam o convívio intenso e o forte vínculo entre o jurista e a esposa, identificando sinais de tirania conjugal inclusive como justificativa para a recusa por Clóvis Beviláqua de diversos cargos e várias honrarias.

Menezes e Azevedo (1959, p. 325) explicam:

que silêncios, vazios, lacunas - e muitos poderiam apostar piamente em sua inexistência." (FANINI, 2009, p. 209)

12 Tal artigo foi publicado também na Revista da Academia Brasileira de Letras, de agosto de 1930, no. 104, com o título "A Academia Brasileira de Letras e o futuro dicionário", p. 458-459. (BRANDÃO, 1989, p. 17) Sobre a discussão sobre a participação de mulheres na Academia Brasileira de Letras, ver Venâncio Filho (2006) e Fanini (2009).

${ }^{13}$ Cabe salientar que em situação anterior, quando Júlia Lopes desejou se candidatar, o jurista não se envolveu na discussão. (FANINI, 2009, p. 224)

R. Inter. Interdisc. INTERthesis, Florianópolis, v.11, n.2, p.138-161, Jul-Dez. 2014
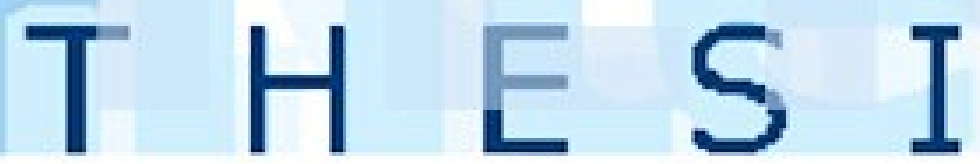
Sabe-se que a esposa de Clóvis o acompanhava por toda parte. Nas sessões da Academia Brasileira de Letras, notava-se a presença de D. Amélia, participando das tertúlias literárias. Pretenderia, nesse caso, a consorte extremosa acompanhar o Ministro do Supremo Tribunal, tomando assento ao seu lado na egrégia corte? A versão, assoalhada por observadores dos hábitos pitorescos do casal, poderia parecer irrisória, se homens notáveis também não estivessem sujeitos, como a maioria dos mortais, à tirania conjugal.

Neder (2002), por sua vez, aborda o casal como uma dupla de intelectuais que em diversas situações atuava de forma una e coesa, afirmando que no casal havia clara predominância de Clóvis.

Reforçando a ideia de proximidade intelectual do casal temos palestra que proferida por Amélia em 1905 no Congresso Scientífico Latino-Americano, realizada no Rio de Janeiro, e publicada em livro como título "Instrução e Educação da Infância", apresenta uma ligação umbilical com texto de Clóvis Beviláqua.

Os quatro biógrafos caracterizam Clóvis Beviláqua como "eterno enamorado", destacando sua verdadeira adoração pelos dotes literários de Amélia Beviláqua:

Não admitia quaisquer restrições às prendas da companheira. (...) Tolerava, de bom grado, críticas que se fizessem a seus trabalhos jurídicos. Defendiaos, sem se irritar com os censores. Mas, que não se pretendesse diminuir o valor da "senhora de meu lar" como costumava chamá-la. (MENEZES; AZEVEDO, 1959, p. 89-90)

Brandão (1989, p. 9-14), por sua vez, identifica no vínculo uma considerável dose de romantismo de Clóvis Beviláqua, o que seria demonstrado por trechos de cartas de amor e poemas do jurista na juventude e que representavam a "pureza" e a "delicadeza" de um afeto que foi dedicado a sua esposa em um convívio de sessenta e um anos de amor, amizade e companheirismo intelectual.

Também é feita referência a Amélia como "extrovertida, inteligente e (que) já demonstrava pendores literários" - fora redatora da revista Lyrio, que Brandão afirma ter sido a primeira revista nacional de senhoras, editada em Pernambuco - e é descrita como baixa, com olhos e cabelos pretos, morena e magra, alegre, inteligente e simpática, tendo recebido boa educação e tendo oportunidade de convívio doméstico com intelectuais e políticos. (BRANDÃO, 1989, p. 43-44) ${ }^{14}$

14 Siqueira (1995, p. 33-54) identifica como anteriores a Lyrio, que circulou entre 1902-1904, os seguintes periódicos voltados ao público feminino: A Mulher (1882), Ave Libertas (1885) e A Rosa (1890 a 1899).

R. Inter. Interdisc. INTERthesis, Florianópolis, v.11, n.2, p.138-161, Jul-Dez. 2014
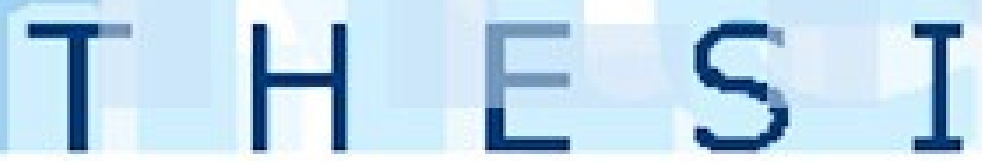
No Rio de Janeiro, embora com parcos recursos, a família Beviláqua manteve professores particulares para as filhas, frequentava cotidianamente restaurantes (o Brahma, o do Hotel Avenida, no qual jantavam todos os dias, e a Confeitaria Colombo) e nos fins de semana recebia diversos convidados:

Aos domingos, parentes, amigos, juristas, estudantes de Direito iam à sua casa pelo prazer do bom convívio. A cordialidade dos anfitriões dava calor às reuniões, Mesa farta, vinhos de excleente qualidade e em profusão. A mesa era renovada várias vezes ao dia, tantas as pessoas que chegavam. (BRANDÃO, 1989, p. 47)

Brandão (1989, p. 20-22 e 45) demonstra a perspectiva íntima da narrativa, por exemplo, na descrição que faz de sua visita à casa do biografado, quando esta era uma criança, nos idos de 1940, e descreve a forma de vestir do casal (formal e modesta), o mobiliário de sua casa na Tijuca, as filhas, os animais de estimação da família (um galo chamado Sassarico, e dois cães, Eolo e Felizardo) e os cuidados de Clóvis com a esposa (que sofria de surdez e esclerose) e que se tratavam carinhosamente como "Miloquinha" e "O Mestre".

Ou ainda:

A família de Beviláqua era simples em tudo, no linguajar, no vestir, nos hábitos alimentares. Não tinha vaidades. É certo que Amélia na mocidade era vaidosa. Usou sempre chapéu e fazia papelote para encrespar os cabelos. Com a idade relaxou. (BRANDÃO, 1989, p. 48)

Os dotes e as ambições intelectuais, assim como o comportamento "coquette" e audacioso, Ihe valeram críticas diversas, sendo a mais grave a acusação de adultério.

Maia (1961, p. 5 e 6) publicou uma biografia em que afirmava no prefácio, entre tantas outras surgidas no centenário do jurista, que era obra "sem caráter crítico ou analítico, mas no evidente sentido panorâmico e panegírico", ambicionando desenvolver um "espírito mais interpretativo do que de pesquisa" e "nada revelando de novo biograficamente terá destacado motivos de ordem secundária, todavia significativos".

Embora o autor reafirme o caráter beatífico de Clóvis Beviláqua pondera que não abordará a sua vida íntima "para não sermos desprimorosos, poupar-lhe-emos a venerável e admirável memória". (MAIA, 1961, p. 8 e 9)

R. Inter. Interdisc. INTERthesis, Florianópolis, v.11, n.2, p.138-161, Jul-Dez. 2014
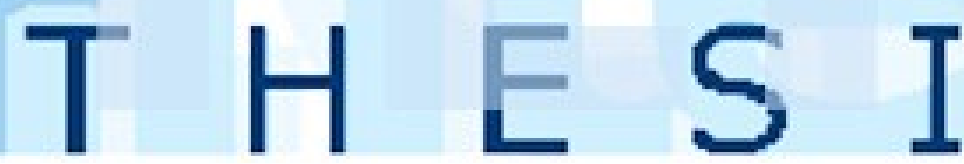
No entanto sobre a esposa faz referência à suposta forma imprópria para a idade com que se vestia e utiliza-se do termo "indiscrições" para qualificar situação delicada envolvendo a escritora e um terceiro.

Segundo o autor, Dulcídio Gonçalves, delegado e ex-aluno do jurista o avisa sobre situação envolvendo Amélia, um outro homem e certa quantia em dinheiro que este recebera desta, o que despertou veemente defesa do jurista enfatizando que não aceitava a sua caracterização como irresponsável ou instável.

Indiferente ao fato de que tal transação pudesse ser originada por dádiva ou extorsão, Maia (1961, p. 9) ainda aponta, em referência direta ao adultério, o contraste da personalidade de Clóvis Beviláqua com a do "modelo nortista" que teria em Euclides da Cunha um exemplo. ${ }^{15}$

Em nenhuma das quatro biografias analisadas ocorre menção ao suposto adultério ou à qualquer comportamento leviano ou imoral de Amélia Beviláqua, pelo contrário, existem referência aos modos exóticos, mas em diversos momentos são reafirmados os vínculos fortes e íntimos da escritora com o jurista.

Uma explicação razoável sobre essa referência à uma suposta tolerância de Clóvis Beviláqua quanto ao adultério da esposa, mais do que originada pelos fatos, pode ser desdobramento do comportamento "moderno" de sua esposa.

Em diversas situações, em seus romances, entrevistas e palestras a escritora deu demonstrações de um pensamento crítico e avançado para sua época, mesmo

\footnotetext{
${ }^{15} \mathrm{Na}$ manhã de 15 de agosto de 1909 o escritor Euclides da Cunha, então com 43 anos, agindo em defesa de sua honra, envolveu-se em um tiroteio com um cadete do exército, Dilermando de Assis, de 21 anos, que mantinha um romance com sua esposa, Anna de Assis, de 37 anos. Disposto a matar ou a morrer invadiu a casa do militar, onde a esposa que o abandonara havia se refugiado, e recebeu quatro tiros que Ihe tiraram a vida. A memória do literato, enquanto "homem de letras", "patriota" e "cientista", dono de uma "vida exemplar", de "prodigioso talento" e "imensa ilustração" tornou-se ao longo dos anos um "culto do escritor como mártir nacional, um culto organizado e de longa duração" (ABREU, 1998, p. 281), no qual o relato biográfico passa a compor a própria obra euclidiana, reforçando sua aura excepcional. Curiosamente Entre os achados nos arquivos por Meira (1990, pp. 302-303), há um trecho da apresentação do primeiro número da revista Ciências e Letras, editada pelo casal Beviláqua, no qual Amélia homenageia escritores que, por já terem falecido, não poderiam contribuir com o órgão literário, tecendo uma rememoração de Euclides da Cunha que merece nota: "Quem poderá esquecer este revolucionário da alma, que viveu sempre torturado por um grande anseio, a lutar com os sentimentos? (...) Seu modo Ihano, sem nenhum amaneiramento na forma simples do trato, o vestuário modesto, e a cabeça grande, um pouco achatada, me fizeram pensar, quando assomou à entrada da sala, num cearense, dos muitos que, de vez em quando, aportados ali, iam nos procurar. (...) Oito dias antes da tragédia, que lhe acabou a existência, encontramo-nos na Avenida, perto da Equitativa. Sua feição era melancólica. Antes desse encontro, nos dissera que, desde a entrada do ano, sofria muito. Ninguém sabia o que passava (...) discorreu sobre os ciúmes. Achava que era um dos mais nobres sentimentos. Esta ligeira palestra assinalou, sem eu saber por que, uma nota de tristeza, no momento da despedida. E eu nunca mais o encontrei."
}

R. Inter. Interdisc. INTERthesis, Florianópolis, v.11, n.2, p.138-161, Jul-Dez. 2014
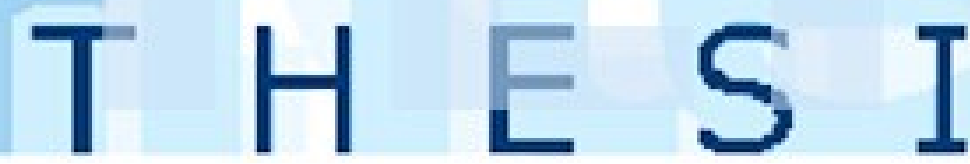
porque vivia em sua casa uma situação que refletia as tensões do período em relação aos vínculos do casamento.

Pois, assim como Clóvis Beviláqua era filho ilegítimo, o casal também apresentava como suas filhas Floriza, Dóris, Veleda e Vitória, embora as duas últimas fossem netas que foram assumidas como filhas para poupar a mãe (Floriza) e elas do estigma de uma união desfeita.

No capítulo IX de seu livro Impressões, intitulado "Qual a sua opinião sobre o divórcio?", encontra-se texto revela uma autora não preocupada em discorrer sobre as leituras que realizou e que considera dignas de destaque, ao contrário dos capítulos anteriores, e justifica seu comedimento alegando ser necessária "uma ciência especial para falar neste assunto, sobre o qual, infelizmente, precários elementos possuo. Além disso, me parece que este inquérito é mais apropriado aos casais desunidos". (BEVILÁQUA, 1929, p. 117)

Além de uma postura modernizante a escritora chamava a atenção para suas ideias durante as discussões sobre o futuro Código Civil, em que defendia existir igual gravidade no adultério, tanto masculino quanto feminino, por ambos caracterizarem quebra da fidelidade conjugal recíproca exigida pela lei, ao contrário de outros juristas que culpabilizavam mais a mulher adúltera.

A velhice da escritora é referenciada pelos diferentes biógrafos, sendo que em Meira (1990) identificam-se os problemas tanto físicos quanto mentais:

\footnotetext{
Procuramos resgatar a imagem de Dona Amélia de Freitas Beviláqua, escritora de bom estilo, gabada por Araripe Júnior, Odilo Costa e muitos outros intelectuais da época. (...) Os trabalhos domésticos, as enfermidades e o tempo destruíram física e mentalmente aquela que, na juventude, fôra uma bela e culta mulher. (MEIRA, 1990, p. 20)
}

Amélia de Freitas Beviláqua, a "Senhora de meu lar", entrava em franca decadência física e mental. (...) As enfermidades, a esclerose principalmente, os trabalhos, as dificuldades, as preocupações, os aborrecimentos de toda ordem, levam o corpo e a alma à desagregação. Amélia era a mulher do lar. (MEIRA, 1990, p. 408)

Já Brandão (1989, p. 108) aponta os problemas com a bebida, quando afirma que após a morte de Clóvis Beviláqua a viúva consumiu treze garrafas de conhaque entre julho e outubro de 1944.

Para além da dona de casa excêntrica, que viveu entre animais domésticos e visitantes, ou da mulher dominadora do marido, desalinhada e de mau aspecto sob o ponto de vista físico, ou da escritora sobre a qual não se tem clareza sobre seu valor R. Inter. Interdisc. INTERthesis, Florianópolis, v.11, n.2, p.138-161, Jul-Dez. 2014 
literário, ou a escritora arrivista que foi alvo de misoginia intelectual, ou ainda a feminista de comportamento audacioso e avançado sob o ponto de vista moral, a memória de Dona Amélia de Freitas Beviláqua, que faleceu em 17 de novembro de 1946, ainda é um espaço de questões e disputas.

\section{PEQUENA CONCLUSÃo}

Embora existam alguns poucos trabalhos acadêmicos sobre Amélia de Freitas Beviláqua, infelizmente nenhum destes propôs uma abordagem biográfica, mas a importância ocupada pelo marido, a intensa relação que manteve com esse ao longo de seis décadas e as particularidades de sua obra e de suas opiniões surgem para nós como uma significativa coleção de vestígios.

Esses numerosos vestígios permitem discutir as bases sobre as quais se estabeleceram a memória da mulher e escritora e desse modo problematizar para além das distinções entre fato e especulação, privacidade e intimidade, relevância e maldizer, hagiografia e demonografia, que são parte do desafio da escrita biográfica.

Como já foi apontado por outros autores interessados no biografismo, o exercício de voyeurismo alimentado pela busca de "fatos bombásticos" ou "facetas desconhecidas" deve ceder espaço à uma real e complexa compreensão da historicidade do personagem, da sociedade e do período em que esse viveu, sem reificar uma vida ou trajetória. ${ }^{16}$

A compreensão da complexidade inerente à condição humana e a percepção da historicidade do personagem, da sociedade e do período tratados permite a superação dos juízos de valor que poderiam reduzir a narrativa biográfica ao julgamento moral em que se vincula a memória do indivíduo à hagiografia ou a demonologia, pois é necessário afirmar-se a individualidade como fragmentária, dinâmica e diversa para além do simples contraste entre dois modelos ou extremos.

Amélia de Freitas Beviláqua, que teve a coragem de desafiar preconceitos, defender maior liberdade, reivindicar plena cidadania para as mulheres e pleitear sua entrada em uma instituição misógina como a Academia Brasileira de Letras, demonstrava uma postura feminista em que sua literatura e sua posição social se

16 Sobre o tema BORGES (2005), BORN (2001), BISSO (2009), BORGES e AVELAR (2010), MARTINS (2004) e SILVA (2009) seriam leituras frutíferas.

R. Inter. Interdisc. INTERthesis, Florianópolis, v.11, n.2, p.138-161, Jul-Dez. 2014
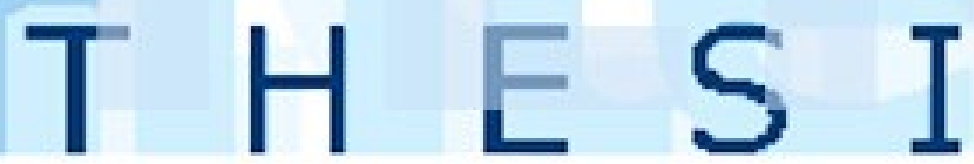
convertem em instrumentos táticos reivindicativos e inventivos, e naquele contexto, capazes de originar alguns de seus estigmas.

Através da memória afirmada pelas biografias sobre seu marido, Clóvis Beviláqua, foi em diversos momentos reduzida aos estereótipos e às simplificações de narrativas que não se preocuparam em entender a complexidade da personalidade e da conduta humana, presente em sua pessoa, na de seu esposo, na de seus contemporâneos e nas intrincadas relações estabelecidas entre esses em sua época.

Se não há biografia definitiva, as fragilidades das biografias do jurista e as distorções da memória de sua esposa são justificativas legítimas para futuros trabalhos acadêmicos sobre os mesmos, de modo que, esperamos, textos melhores virão.

R. Inter. Interdisc. INTERthesis, Florianópolis, v.11, n.2, p.138-161, Jul-Dez. 2014
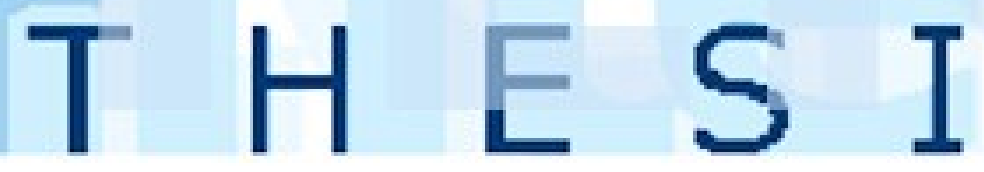
AMELIA WAS A REAL WOMAN: THE MEMORY OF AMELIA CAROLINA DE FREITAS BEVILAQUA IN THE BIOGRAPHIES OF HER HUSBAND, CLOVIS BEVILAQUA.

\begin{abstract}
:
Based on Clovis Bevilaqua's four biographies which present three stigmas of the character - being the son of a priest, engaged in a large grammatical legal controversy with Rui Barbosa in making the Civil Code of 1917 and married to a wife of exotic modes - we discuss the built memory of Amelia Carolina Freitas Bevilaqua, who is marked as a pioneer of the feminist movement in Brazil and also upstart writer who aspired to join the Brazilian Academy of Letters. Among other negative adjectives, she was sloppy, not vain and misaligned in dress, futile or adulterous.

Keywords: Clovis Bevilaqua. Amelia Carolina de Freitas Bevilaqua. Biography. Memory.

\section{AMELÍA BEVILAQUA QUE ERA MUJER DE VERDAD: LA MEMORIA CONSTRUIDA DE LA ESPOSA DE CLOVIS BEVILAQUA.}

\title{
Resumen:
}

A partir de cuatro biografías sobre el jurista Clóvis Beviláqua, que presentan tres estigmas del personaje - ser hijo de un cura, involucrarse en una gran polémica jurídico-gramatical con Rui Barbosa en la confección del Código Civil de 1917 e tener una esposa de modos exóticos - se discute como fue construida la memoria de Amelia Carolina de Freitas Bevilaqua, marcada como pionera del movimiento feminista en Brasil y también como una escritora advenediza que aspiraba a entrar en la Academia Brasileña de Letras; ama de casa relajada, mujer poco vanidosa y desaliñada en el vestir; esposa adúltera, entre otros adjetivos negativos.

Palabras clave: Clovis Bevilaqua. Amelia Carolina de Freitas Bevilaqua. Biografía. Memoria. 


\section{REFERÊNCIAS}

BEVILÁQUA, Amélia de Freitas. Instrução e Educação da Infância. Revista Literatura e Direto, 1907. Fonte: Biblioteca Lúcio de Mendonça da Academia Brasileira de Letras.

BEVILÁQUA, Amélia de Freitas. Impressões. Rio de Janeiro: Typografia Besnard Freres, 1929.

BEVILÁQUA, Amélia de Freitas. Amélia Beviláqua e a Academia Brasileira de Letras: documentos histórico-literários. Rio de Janeiro: Besnard Frères, 1930.

BEVILÁQUA, Amélia de Freitas. Divagações sobre a consciência: conferência. Rio de Janeiro: Oficina Gráfica Borsoi, 1931.

BEVILÁQUA, Amélia. Revista O Lyrio. Recife: 8 de novembro de 1902 a junho de 1904.

\section{- Livros e artigos consultados}

ABREU, Regina. O Enigma de Os Sertões. Rio de Janeiro: Funarte/Rocco, 1998.

ARFUCH, Leonor. O espaço biográfico: dilemas da subjetividade contemporânea. Rio de Janeiro: UERJ, 2010.

AVELAR, Alexandre de Sá. A biografia como escrita da História: possibilidades, limites e tensões. Dimensões. Vitória: UFES, vol. 24, p. 157-172, 2010.

BESSE, Susan K. Modernizando a Desigualdade: reestrutura da ideologia de gênero no Brasil 1914-1940. São Paulo: Edusp, 1999.

BORGES, Vavy Pacheco. Grandezas e Misérias da Biografia, In: PINSKY, Carla Bassanezi. Fontes Históricas. São Paulo: Contexto, 2005, p. 203-233.

BORGES, Vavy Pacheco. O "eu" e o "outro" na relação biográfica: algumas reflexões, In: NAXARA, Márcia. MARSON, Izabel. BREPOHL, Marion. Figurações do outro. Uberlândia: UFU, 2009, p. 225-238. 
BORN, Claudia. Gênero, trajetória de vida e biografia: desafios metodológicos e resultados empíricos. Sociologias. Porto Alegre: UFRS. n.5, p. 240-265, 2001.

BRACKSCHREIDER, Paula R. Reflections on biography. Estados Unidos: Oxford University Press, 2001.

DOSSE, François. El arte de la biografia: entre historia y ficcion. México: Universidad IberoAmericana, 2007.

FALCI, Miridan Britto Knox. Amélia de Freitas Beviláqua: A intelectual piauiense avançada, s.d. Disponível em < www.fnt.org.br/dwp.php?a=b46d45af1e.pdf\&id=109 $>$ Visitado em 21/11/2011.

FALCI, Miridan Britto. As mulheres do sertão nordestino, In: PRIORE, Mary Del (org.). História das Mulheres no Brasil. São Paulo: Contexto, 2004, p.241 a 277.

FANINI, Michele Asmar. Fardos e Fardões Mulheres na Academia Brasileira de Letras (1987-2003). São Paulo, 2004. Tese (Doutoramento em História Social). USP: FFCHL.

LORIGA, Sabina. O pequeno x: da biografia à história. Belo Horizonte: Autêntica, 2011.

MALUF, Mariana e MOTT, Maria Lúcia. Recôndito do mundo feminino. In: SEVCENKO, Nicolau. (org.) História da Vida Privada no Brasil - República: da Belle époque à Era do Rádio. São Paulo: Companhia da s Letras, 1998. Vol. 3, p. 368-421.

MARTINS, Fernando. Historiografia, biografia e ética. Análise Social. Lisboa:

Instituto de Ciências Sociais da Universidade de Lisboa, n. 171, p. 391-408, 2004.

MEIRA, Silvio Meira. Clóvis Beviláqua: sua vida, sua obra. Fortaleza: Edições Universidade Federal do Ceará, 1990.

MENDES, Algemira de Macêdo. Amélia Beviláqua e Maria Firmina dos Reis na história da literatura: representação, imagens e memórias nos séculos XIX e XX. Porto Alegre, 2006. Tese (Doutorado em Lingüística e Letras). Pontifícia Universidade Católica do Rio Grande do Sul. 
RODRIGUES, João Paulo Coelho de Souza. A dança das cadeiras: literatura e política na Academia Brasileira de Letras (1869-1913). Campinas: Ed. da Unicamp, 2001

SILVA, Wilton C. L. Biografias: construção e reconstrução da memória. Revista Fronteiras, v. 11, p. 151-166, 2009.

VENÂNCIO FILHO, Alberto. As mulheres na Academia. Revista Brasileira. Rio de Janeiro: Academia Brasileira de Letras, Fase VII, out.-nov., Ano XIII, no. 49, p. 7-44, 2006.

\section{Artigo:}

Recebido em Julho de 2014

Aceito em Outubro de 2014

R. Inter. Interdisc. INTERthesis, Florianópolis, v.11, n.2, p.138-161, Jul-Dez. 2014 